\title{
Induction of allogenic T-cell hyporesponsiveness by galectin-1-mediated apoptotic and non-apoptotic mechanisms
}

\author{
GA Rabinovich ${ }^{\star, 1,2,4}$, RE Ramhorst ${ }^{1,2,4}$, N Rubinstein ${ }^{1,2}$, \\ A Corigliano $^{1}$, MC Daroqui ${ }^{3}$, EB Kier-Joffé ${ }^{3}$ and L Fainboim ${ }^{1,2}$ \\ ${ }^{1}$ Division of Immunogenetics, Hospital de Clínicas 'José de San Martín', \\ University of Buenos Aires, Argentina \\ 2 Department of Microbiology, School of Medicine, University of Buenos Aires, \\ Argentina \\ ${ }^{3}$ Research Area, Institute for Oncology 'Angel Roffo', University of Buenos \\ Aires, Argentina. \\ ${ }^{4}$ These authors contributed equally to this work \\ * Corresponding author: GA Rabinovich, División de Inmunogenética, Hospital \\ de Clínicas 'José de San Martín'. Facultad de Medicina, Universidad de Buenos \\ Aires, Córdoba 2351, 3er Piso (1120) Buenos Aires, Argentina. \\ Tel: 0054-11-5950-8755/8756/8757; Fax: 0054-11-5950-8758; \\ E-mail: gabyrabi@ciudad.com.ar
}

Received 20.11.01; revised 3.1.02; accepted 8.1.02

Edited by $\mathrm{G}$ Ciliberto

\begin{abstract}
Galectin-1, a $\beta$-galactoside-binding protein expressed at sites of T-cell activation and immune privilege, has shown specific immunosuppressive properties. Because of the implications of this protein in T-cell tolerance and its potential use to avoid graft rejection, we investigated the immunosuppressive effects of galectin-1 in the course of the human allogenic Tcell response. Galectin-1 induced a dose- and carbohydratedependent inhibition of the allogenic T-cell response. Addition of galectin-1 to alloreactive lymphocytes resulted in significant apoptosis of CD45R0-positive cells. This negative regulatory effect was accompanied by caspase activation, $\mathrm{Bcl}-2$ downregulation and was prevented by addition of exogenous IL-2. In addition, a significant decrease of IFN- $\gamma$ production was detected in the non-apoptotic cell population, following exposure of alloreactive lymphocytes to galectin-1. Moreover, the immunosuppressive activity of this protein did not involve TGF- $\beta$-mediated mechanisms. Since galectin- 1 is expressed by activated $T$ cells and could be acting by an autocrine negative loop to control human T-cell reactivity, we finally examined the regulated expression of this protein throughout the allogenic T-cell response. Expression of endogenous galectin-1 was detected at $24 \mathrm{~h}$ of cell culture, reaching its maximal levels after $72 \mathrm{~h}$ of allostimulation. The present study sets the basis for a potential use of galectin- 1 as a selective immunosuppressive agent to limit T-cell-mediated reactivity during the effector phase of the alloimmune response.

Cell Death and Differentiation (2002) 9, 661-670. DOI: 10.1038/ sj/cdd/4401009
\end{abstract}

Keywords: galectin-1; apoptosis; alloimmune response; tolerance

Abbreviations: Gal-1, galectin-1; GVHD, graft versus hostdisease; PI, propidium iodide; TDG, thiodigalactoside; ZVAD-fmk, benzyloxycarbonyl-Val-Ala-Asp-fluoromethylketone

\section{Introduction}

Galectin-1 (Gal-1) is a member of a growing family of animal lectins, which are highly conserved throughout the evolution and share sequence similarities in the carbohydrate recognition domain. ${ }^{1}$ Galectin-1 is expressed by thymic epithelial cells, ${ }^{2}$ macrophages, ${ }^{3,4}$ activated T cells, ${ }^{5}$ stimulated B cells ${ }^{6}$ and 'immunologically privileged' tissues, such as placenta, testis and tumors. ${ }^{1}$ This $\beta$-galactoside-binding protein is secreted as a non-covalently linked homodimer with two ligand binding sites capable of mediating cell-cell, cellmatrix interactions, through recognition of polylactosamine structures on cell surface glycoconjugates. ${ }^{2,7-13}$

By crosslinking T-cell surface glycoproteins, ${ }^{10} \mathrm{Gal}-1$ has been shown to induce apoptosis of immature thymocytes and activated, but not resting $\mathrm{T}$ cells, through Erk phosphorylation and activation of specific transcription factors. ${ }^{4,9,14-18}$ Recent observations suggest that this carbohydrate-binding protein modulates T-cell receptor (TCR)-mediated apoptosis through partial TCR- $\zeta$ chain phosphorylation. ${ }^{17}$ Moreover, we have shown that Gal-1, at low concentrations $(<1 \mu \mathrm{M})$, inhibits T-cell-matrix interactions and reduces proinflammatory cytokine secretion, but does not induce apoptosis. ${ }^{19}$ The immunomodulatory and anti-inflammatory effects of this carbohydratebinding protein have been also validated in vivo in experimental models of autoimmunity and inflammation. ${ }^{20-24}$ We have demonstrated, using gene therapy strategies, that Gal-1 ameliorates inflammation and suppresses the autoimmune response in a murine experimental model of rheumatoid arthritis. ${ }^{20}$ Gal- 1 treatment of arthritic mice increased T-cell susceptibility to activationinduced cell death and resulted in a strong shift from a Th1 to a Th2 cytokine profile. ${ }^{20}$ This new wealth of information suggests that Gal-1 could be used as a selective immunosuppressive agent to shut-off T-cell effector functions under several pathological conditions.

Alloantigen-reactive $T$ cells represent the major barrier to successful organ transplantation. ${ }^{25,26}$ Standard immunosuppressive drugs do not specifically target alloreactive $T$ cells and must be given for the lifetime of the individual, resulting in significant morbidity and mortality. ${ }^{25}$ Recent studies highlighted a major role for apoptosis in the establishment of new protocols for the induction of allograft 
acceptance and transplantation tolerance. ${ }^{27-34}$ Although Fas $L$ and TNF- $\alpha$ have been shown to mediate many of these immunosuppressive effects, ${ }^{29-33}$ it has been recently proposed that alternative pathways might participate in alloantigen-driven T-cell death. ${ }^{34}$

The present study was conducted to investigate the immunomodulatory properties, mechanisms of action and regulated expression of Gal-1 in the course of an allogenic T-cell response.

\section{Results}

Gal-1 modulates the allogenic T-cell response in a dose- and carbohydrate-dependent manner

To investigate the immunosuppressive potential of Gal-1 in the course of an alloimmune response, we first cultured PBMC from fully-HLA mismatched donors for 5 days in the presence or absence of recombinant Gal-1 at increasing concentrations of 2, 4, 40 and $100 \mu \mathrm{g} / \mathrm{ml}$. As shown in Figure 1A, Gal-1 induced a dose-dependent inhibition of the allogenic T-cell proliferative response, as shown by reduced thymidine uptake (22, 37, 61 and $80 \%$ inhibition for $2,4,40$ and $100 \mu \mathrm{g} / \mathrm{ml}$ respectively; $P<0.01$ for 4,40 and $100 \mu \mathrm{g} / \mathrm{ml}$ ). As a control, autologous resting cells did not show any significant change in their proliferative response, when exposed to this $\beta$-galactoside-binding protein at any of the concentrations tested (data not shown). To investigate whether inhibition of the allogeneic T-cell response by Gal-1 relies on its carbohydrate-binding properties, we incubated alloreactive lymphocytes with different concentrations of this protein in the presence of $0.1 \mathrm{M}$ thiodigalactoside (TDG). This $\beta$-galactoside-specific sugar was able to almost completely prevent inhibition of the alloresponse induced by Gal-1 (4 $\mu \mathrm{g} /$ $\mathrm{ml}$ ). However, prevention was partial when Gal-1 was used at $40 \mu \mathrm{g} / \mathrm{ml}$ (Figure 1B). Interestingly, incubation of alloreactive lymphocytes with Gal-1 in the presence of its specific antibody (Ab), not only prevented inhibition, but also induced a slight but significant increase of the proliferative response, in comparison with alloreactive cells cultured in the absence of Gal-1 (Figure 1C; $P<0.05$ ). This suggests that endogenous Gal-1 could be inhibited in the presence of its specific Ab. A similar effect was observed when alloreactive lymphocytes were cultured in the presence of the anti-Gal-1 $\mathrm{Ab}$ alone (Figure 1C).

To gain insight into the cellular and molecular mechanisms implicated in Gal-1-induced inhibition of the allogenic response, alloreactive lymphocytes were cultured in the presence of Gal-1 $(40 \mu \mathrm{g} / \mathrm{ml})$ and processed for apoptosis detection. Propidium iodide $(\mathrm{PI})$ staining revealed a timedependent increase of subdiploid DNA content, when cells were allostimulated in the presence of Gal-1 for $0,24,48 \mathrm{~h}$ and 5 days (Figure $2 \mathrm{~A}$, histograms). The kinetic analysis after subtraction of the corresponding controls in the absence of Gal-1 is shown in Figure 2B. Because Gal-1 kills activated $\mathrm{T}$ cells bearing the polylactosamine-enriched CD45R0 splicing product, we analyzed the susceptibility of CD45R0-positive cells to Gal-1-induced apoptosis in the context of the allogenic response. For this purpose, we first selected CD45R0 positive cells by using a PE-conjugated
A

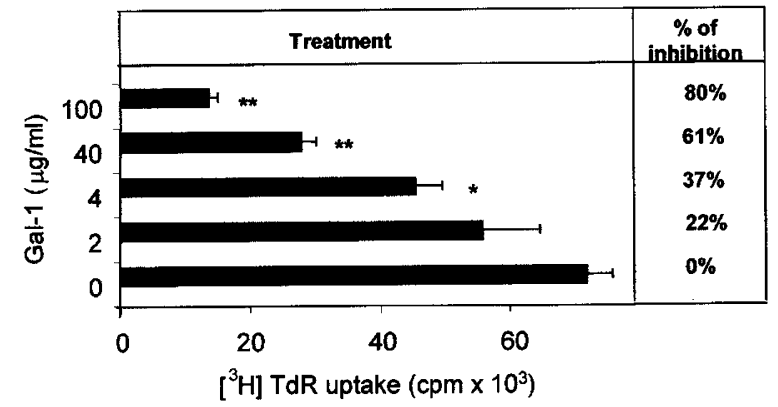

B

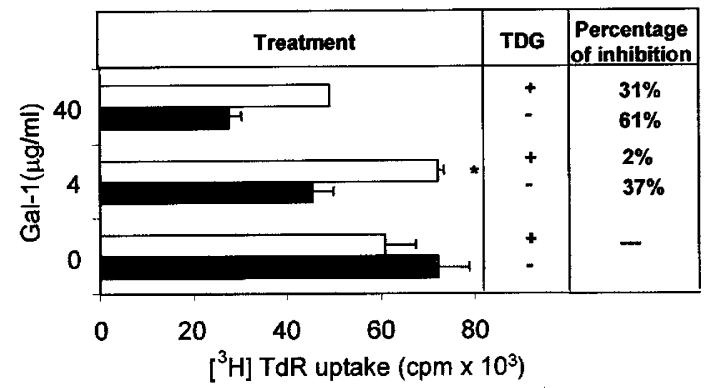

C

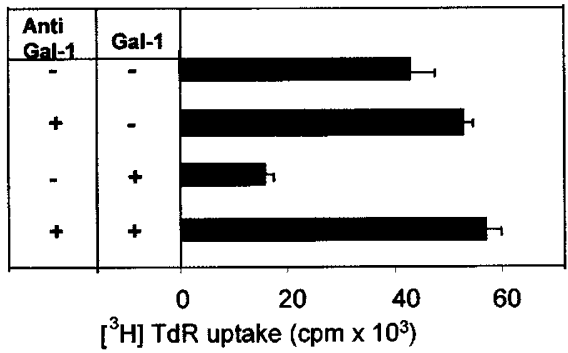

Figure $1 \mathrm{Gal}-1$ inhibits the allogenic response in a carbohydrate-dependent manner. (A) Fully HLA-mismatched responder $\left(1 \times 10^{5}\right.$ cells $\left./ \mathrm{ml}\right)$ and mitomycin-treated stimulator PBMCs $\left(1 \times 10^{5} \mathrm{cells} / \mathrm{ml}\right)$ were co-cultured in 96 well microtiter plates in the absence or presence of Gal-1 (2, 4, 40 and $100 \mu \mathrm{g} /$ $\mathrm{ml}$ ). (B): Allogeneic PBMCs were co-cultured with Gal-1 (4 and $40 \mu \mathrm{g} / \mathrm{ml})$ in the absence (solid bars) or in the presence (open bars) of $0.1 \mathrm{M}$ thiodigalactoside (TDG). (C) Allogeneic PBMCs were co-cultured in the absence or presence of Gal-1 $(40 \mu \mathrm{g} / \mathrm{ml})$ and the specific anti-Gal-1 Ab (1:100). After 5 days, $\left[{ }^{3} \mathrm{H}\right] \mathrm{TdR}$ was added for $18 \mathrm{~h}$ and uptake was determined using a $\beta$-scintillation counter. Data are expressed as c.p.m. \pm S.E.M of triplicate determinations and as percentages of inhibition of cell proliferation. Results are representative out of five independent experiments using different healthy donors and different allogeneic combinations. ${ }^{*} P_{\text {Gal } 4 \mu \mathrm{g} / \mathrm{ml}}<0.01 \mathrm{vs}$ cells cultured in medium alone or TDG. ${ }^{* *} P_{\text {Gal }} 40$ and $100 \mu \mathrm{g} / \mathrm{ml}<0.001$ vs cells cultured in medium alone

anti-CD45R0 mAb, and then measured the frequency of early and late apoptotic cells by FITC-annexin-V and PI staining (Figure 2C). Treatment with this sugar-binding protein resulted in $\sim 25 \%$ of early apoptotic CD45R0+ lymphocytes (annexin- $\mathrm{V}$ positive, $\mathrm{PI}$ negative) and $\sim 28 \%$ of cells positive for both FITC-annexin-V and PI (Figure 2C, right panel). Alloreactive lymphocytes cultured in the absence of Gal-1 were used as a negative control of apoptosis (Figure 2C, left panel).

Galectin-1 was also found to affect cytokine secretion independently of its pro-apoptotic properties. ${ }^{14,19,20}$ There- 
A
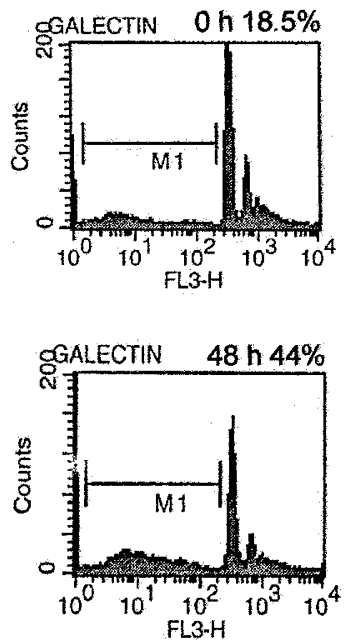
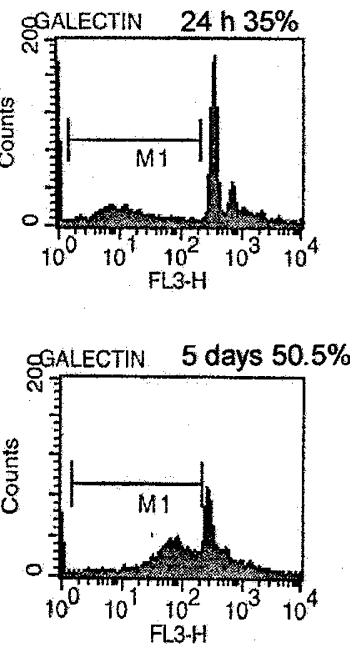

B

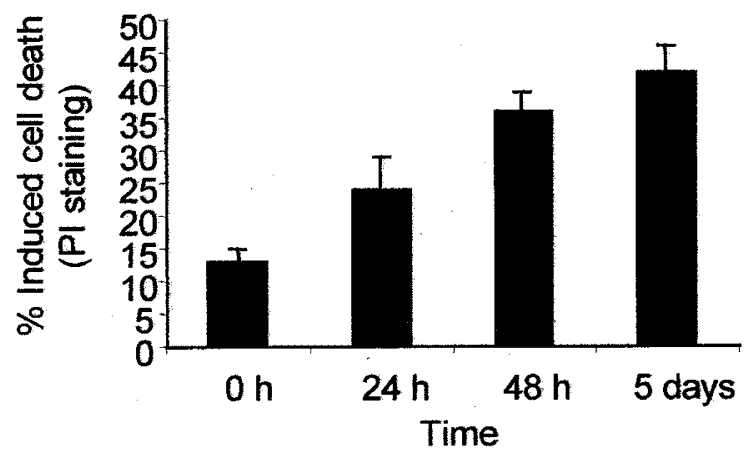

\section{$\mathrm{CD} 45 \mathrm{RO}^{+}$gated}

C

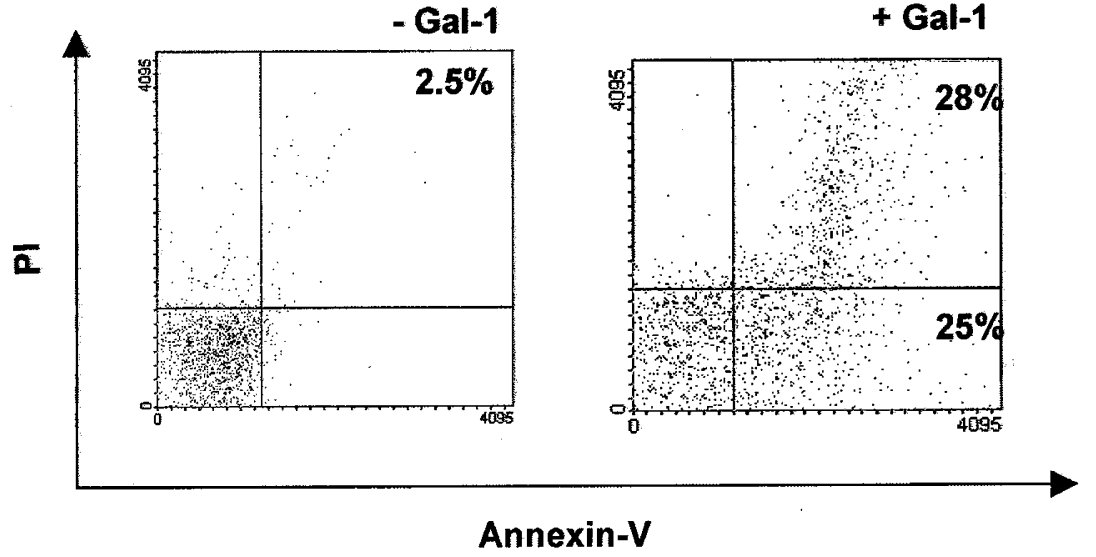

D

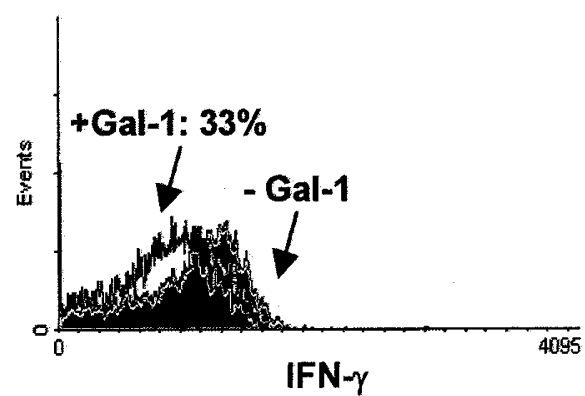

Figure $2 \mathrm{Gal}-1$ induces apoptosis of $\mathrm{CD} 45 \mathrm{R} 0^{+}$cells and modulates IFN- $\gamma$ production following allogenic stimulation. Fully HLA-mismatched responder $\left(1 \times 10^{5}\right.$ cells $/ \mathrm{ml})$ and mitomycin-treated stimulator PBMCs $\left(1 \times 10^{5}\right.$ cells $\left./ \mathrm{ml}\right)$ were co-cultured in the absence or in the presence of Gal- $1(40 \mu \mathrm{g} / \mathrm{ml})$ for the indicated periods and analyzed for apoptosis and IFN- $\gamma$ production. (A) Subdiploid DNA content measured by PI staining. (B) Kinetics of PI incorporation of alloreactive lymphocytes, after subtraction of the corresponding controls as indicated in Materials and Methods. (C) Apoptosis of CD45R0 $0^{+}$cells measured by annexin-V and PI staining (D) Intracytoplasmic IFN- $\gamma$ production of non-apoptotic cells exposed to Gal-1. Percentages of cell death were determined as indicated in Materials and Methods. Results are representative out of three independent experiments using different healthy donors 
fore, we also analyzed whether modulation of IFN- $\gamma$ production (a major Th1 proinflammatory cytokine involved in the allogenic response) contributed to the immunosuppressive effects triggered by Gal-1. In order to discriminate between the effects of Gal-1 on cytokine production and cell death, and to avoid potential complications due to nonspecific uptake of Abs by apoptotic cells, annexin-V positive lymphocytes were electronically excluded (gated out) and intracellular IFN- $\gamma$ was determined by FACS analysis in the non-apoptotic cell population. Addition of Gal-1 to allogenic cell cultures resulted in 33\% reduction of intracellular IFN- $\gamma$ levels after 5 days of culture (Figure 2D). Taken together, these results suggest that Gal-1 inhibits the allogenic response in a dose- and carbohydrate-dependent manner through induction of T-cell apoptosis and inhibition of IFN- $\gamma$ production. Inhibition of this cytokine was not likely the result of killing IFN- $\gamma$-producing cells, since dead cells were excluded from analysis by automatic gating after annexin staining. Hence, apoptotic and non-apoptotic mechanisms might contribute to Gal-1-induced immunosuppression during the course of an alloimmune response.

\section{Galectin-1 delivers inhibitory signals through $\mathrm{Bcl}-2-$ and caspase-dependent pathways}

Since the response of a cell to death/proliferation signals, is modulated by members of the $\mathrm{Bcl}-2$ protein family, ${ }^{35}$ we analyzed expression of $\mathrm{Bcl}-2$ by immune cells responding during the mixed lymphocyte culture in the absence or presence of Gal-1. As shown in Figure 3A, Bcl-2 expression reached its maximal levels within $24 \mathrm{~h}$ of allostimulation in the absence of Gal-1 and declined only after $72 \mathrm{~h}$ of cell culture. When Gal-1 was added to alloreactive lymphocytes at the initiation of the cell culture, Bcl-2 expression also peaked after $24 \mathrm{~h}$, but immediately decreased in a time-dependent manner (Figure 3A). The immunoreactive profiles are shown in Figure $3 B$. This effect was consistent with the kinetics of apoptosis observed in Figure 2A,B.

Since various, but not all apoptotic stimuli deliver intracellular death signals through recruitment of specific caspases, ${ }^{36,37}$ we examined whether ZVAD-fmk, a broadspectrum caspase inhibitor, was able to overcome the block in proliferation triggered by Gal-1. As shown in Figure 4 , addition of ZVAD-fmk $(50 \mu \mathrm{M})$ at the initiation of the cell culture was able to prevent cell growth arrest induced by Gal-1. Moreover, addition of ZVAD-fmk did not affect cellular proliferation in the absence of Gal-1. These results suggest that Gal-1 delivers intracellular inhibitory signals through $\mathrm{Bcl}-2$ - and caspase-dependent pathways.

\section{Interleukin-2 overcomes Gal-1-induced-inhibition of the allogenic T-cell response and prevents Gal-1-induced apoptosis}

Interleukin-2 (IL-2) has been shown to rescue antigen-specific T cells from apoptosis induced by a variety of stimuli, such as growth factor deprivation, radiation and dexamethasone. ${ }^{38,39}$ Since Gal-1 antagonizes TCR-induced IL-2 production, ${ }^{14}$ we investigated whether addition of exogenous IL-2 could overcome inhibition of the alloimmune response and
A

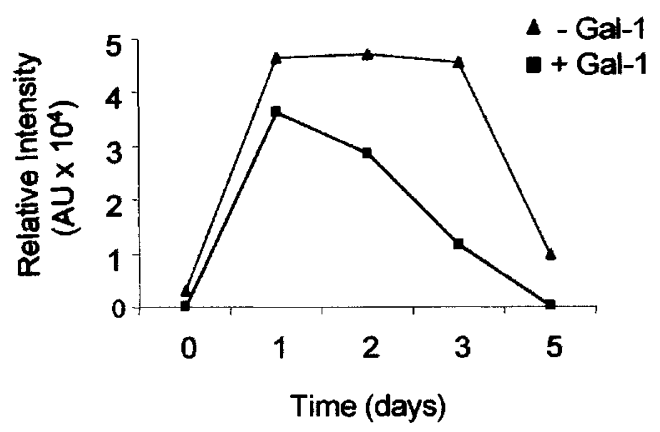

B

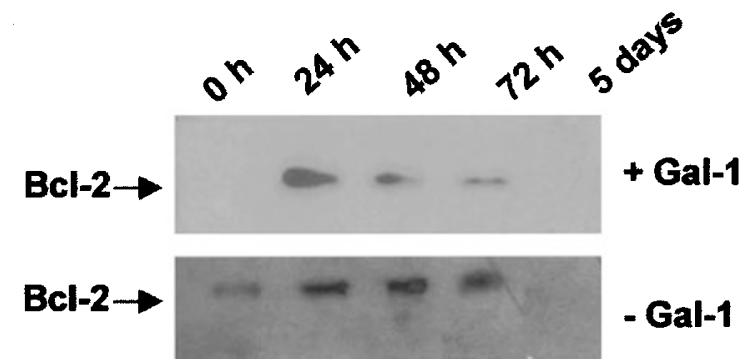

Figure 3 Gal-1 modulates Bcl-2 expression levels in the course of the alloimmune response. Fully HLA-mismatched responder $\left(1 \times 10^{5} \mathrm{cells} / \mathrm{ml}\right)$ and mitomycin-treated stimulator PBMCs $\left(1 \times 10^{5}\right.$ cells $\left./ \mathrm{ml}\right)$ were co-cultured in the absence or in the presence of Gal-1 $(40 \mu \mathrm{g} / \mathrm{ml})$ for the indicated time periods. Cells were harvested and lysed in the presence of protease inhibitors. Equal amounts of protein were subjected to SDS-PAGE on a $15 \%$ polyacrylamide slab gel and immunoblotted with an anti-Bcl-2 polyclonal $A b(1: 2000)$. Immunoreactive protein bands were semiquantified by densitometry and expressed as relative arbitrary units (AU). (A) Kinetic analysis of $\mathrm{Bcl}-2$ expression in the course of a normal allogenic response in the absence or presence of Gal-1. (B) Western blot assay of representative allogeneic cultures in the presence (upper panel) or absence (lower panel) of Gal-1. Results are representative out of three independent experiments using different healthy donors

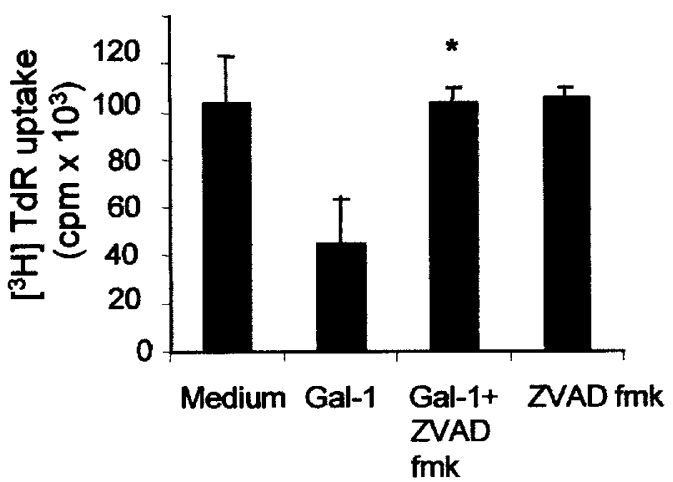

Figure 4 Gal-1 inhibits the allogeneic response through a caspasedependent pathway. Fully HLA-mismatched responder $\left(1 \times 10^{5}\right.$ cells $\left./ \mathrm{ml}\right)$ and mitomycin-treated stimulator PBMCs $\left(1 \times 10^{5}\right.$ cells $\left./ \mathrm{ml}\right)$ were co-cultured in 96well microtiter plates with Gal-1 in the absence or presence of $50 \mu \mathrm{M}$ ZVAD-fmk (a broad range caspase inhibitor). After 5 days, $\left[{ }^{3} \mathrm{H}\right] \mathrm{TdR}$ was added for $18 \mathrm{~h}$ and uptake was determined using a $\beta$-scintillation counter. Data are expressed as c.p.m. \pm S.E.M. of triplicate determinations from a representative out of two independent experiments using different healthy donors. ${ }^{*} P_{\text {Gal-1+ZVAD-fmk }}$ $<0.05$ vs Gal-1 
apoptosis induced by this lectin. IL-2 was used at submitogenic concentrations $(20 \mathrm{U} / \mathrm{ml})$, which did not affect thymidine incorporation, when added alone to cell cultures at different periods (Figure 5A). Incorporation of this cytokine $24 \mathrm{~h}$ after the initiation of the cell culture, was able to completely overcome Gal-1-induced inhibition of alloreactive lymphocytes $(P<0.01)$ (Figure 5A). This effect did not occur when this cytokine was incorporated after 5 days of allostimulation. Expression of CD25 (IL-2R $\alpha$ ) was not affected by Gal-1 during the allogenic response, indicating receptor availability for IL-2 (data not shown).

To determine whether IL-2 also prevented Gal-1-induced apoptosis, we stimulated lymphocytes for $18 \mathrm{~h}$ in the presence or absence of Gal-1 and IL-2. At the indicated

A

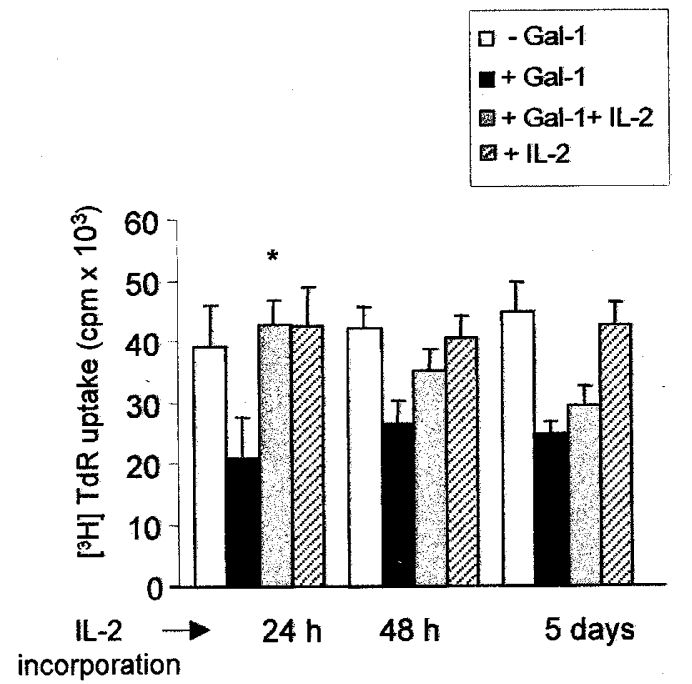

B

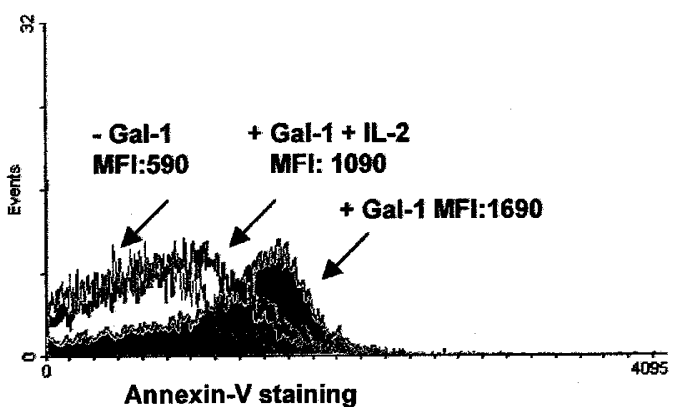

Figure 5 IL-2 overcomes Gal-1-induced inhibition of the alloimmune response and prevents apoptosis. (A) Fully HLA-mismatched responder $\left(1 \times 10^{5}\right.$ cells $\left./ \mathrm{ml}\right)$ and mitomycin-treated stimulator PBMCs $\left(1 \times 10^{5} \mathrm{cells} / \mathrm{ml}\right)$ were co-cultured in 96-well microtiter plates in the absence or in the presence of Gal-1 $(40 \mu \mathrm{g} / \mathrm{ml})$. At the indicated times, recombinant IL-2 was incorporated to cell cultures at a submitogenic concentration $(20 \mathrm{U} / \mathrm{ml})$. After 5 days, $\left[{ }^{3} \mathrm{H}\right] \mathrm{TdR}$ was added for $18 \mathrm{~h}$ and uptake was determined using a $\beta$-scintillation counter. Data are expressed as c.p.m. \pm S.E.M. of triplicate determinations. (B) Lymphocytes from normal donors were incubated for $18 \mathrm{~h}$ with an anti-CD3 $\mathrm{mAb}$ in the absence or in the presence of Gal-1 or Gal-1 plus IL-2 and analyzed for apoptosis by annexin- $V$ staining. Results are representative out of three independent experiments using different healthy donors. ${ }^{*} P_{\text {Gal+IL-2 (at } 24 \mathrm{~h} \text { ) }}$ $<0.001$ vs Gal-1 period, cells were processed for annexin-V staining. As shown in Figure 5B, IL-2 was able to prevent apoptosis induced by Gal-1, when this lectin was used at a concentration of $40 \mu \mathrm{g} / \mathrm{ml}$. Since long-term expression of immunosuppressive agents might have secondary effects in vivo, our results suggest that Gal-1 inhibitory effects might be carefully controlled by addition of exogenous IL-2.

\section{Galectin-1 inhibits the allogenic T-cell response through TGF- $\beta$-independent mechanisms}

Since TGF- $\beta$ is a major immunosuppressive cytokine involved in allogenic T-cell homeostasis, ${ }^{40,41}$ we also analyzed whether the suppressive effects of Gal-1 were also sustained by an increase in TGF- $\beta$ activity. For this purpose, we assessed TGF- $\beta$ expression and bioactivity during the course of the alloimmune response. As shown by Western blot analysis, using a TGF- $\beta$ detection kit, Gal-1 was not able to trigger any change in TGF- $\beta$ expression, which peaked at $24 \mathrm{~h}$ (or $48 \mathrm{~h}$ in some experiments) and

A

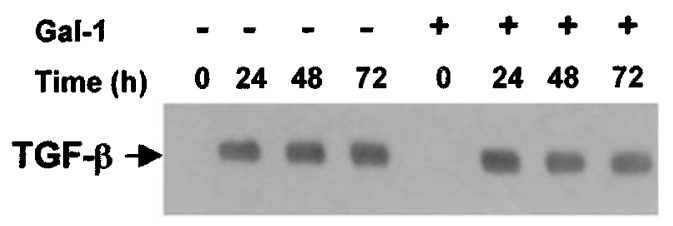

B

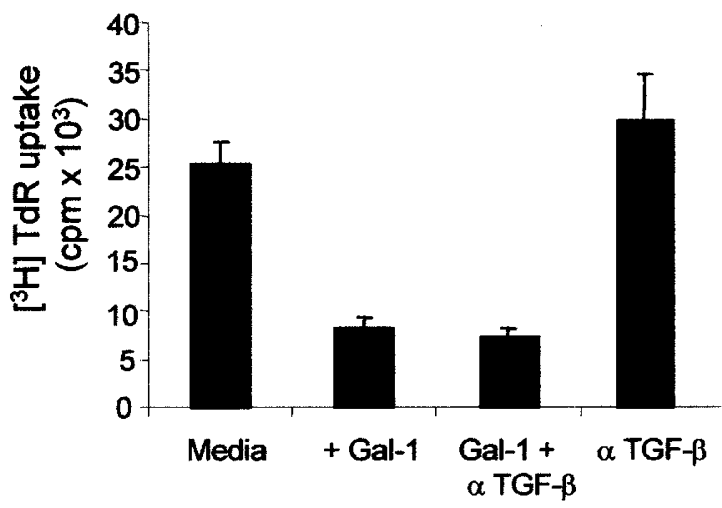

Figure 6 Gal-1 suppresses the alloimmune response through TGF- $\beta$ independent mechanisms. Fully HLA-mismatched responder $\left(1 \times 10^{5}\right.$ cells/ $\mathrm{ml})$ and mitomycin-treated stimulator PBMCs $\left(1 \times 10^{5}\right.$ cells $\left./ \mathrm{ml}\right)$ were co-cultured in 96-well microtiter plates in the absence or presence of Gal-1 $(40 \mu \mathrm{g} / \mathrm{ml})$. (A) Cells were collected from different wells after the indicated periods. Samples were lysed and equal amounts of protein were subjected to SDS-PAGE and analyzed by Western blot analysis using a TGF- $\beta$ detection kit as per the manufacturer's recommendations. A representative of two independent experiments is shown. (B) For neutralization experiments, a pan-specific anti-TGF- $\beta$ mAb was added at the initiation of the cell culture in order to block endogenous TGF- $\beta$ production. After 5 days, $\left[{ }^{3} \mathrm{H}\right] \mathrm{TdR}$ was added and uptake was determined for the final $18 \mathrm{~h}$. Data are expressed as c.p.m. \pm S.E.M. of triplicate determinations. Results are representative out of three independent experiments using different healthy donors 
remained intact during the course of the allogenic response both in the absence or presence of this $\beta$-galactosidebinding protein (Figure 6A). This result was further strengthened by the lack of an additive inhibitory response of the TGF- $\beta$-sensitive Mv1Lu cell line, ${ }^{42}$ when exposed to different dilutions of acidified supernatants obtained from Gal-1-treated allogenic cells ( 4 and $40 \mu \mathrm{g} / \mathrm{ml}$ ), in comparison with Mv1Lu cells exposed to acidified supernatants from normal allogenic cell cultures (Table 1). Similar results were obtained when non-acidified supernatants were tested on Mv1Lu cells to assess only bioactive TGF- $\beta$. Confirming these findings, a pan-specific anti-TGF- $\beta$ neutralizing $\mathrm{mAb}$ was not able to overcome Gal-1-induced inhibition of the allogenic T-cell response, when added at the initiation of the cell culture (Figure 6B). Cells incubated with medium alone or exposed to the anti-TGF- $\beta$ mAb in the absence of Gal-1, were used as controls. In the absence of Gal-1, the neutralizing $\mathrm{mAb}$ slightly increased thymidine uptake, compared to cells cultured in medium alone (Figure 6B). This could probably indicate the ability of the antibody to neutralize part of bioactive TGF- $\beta$ generated early during the course of the alloimmune response. ${ }^{40,41}$ Taken together, these results suggest that Gal-1 does not increases the levels of total, latent or bioactive TGF- $\beta$, and at least in the allogenic setting, the negative regulatory effect of Gal-1 does not rely on TGF- $\beta$-dependent mechanisms.

\section{Galectin-1 is differentially expressed during the allogenic T-cell response}

Galectin-1 is expressed by antigen presenting cells, stromal cells and activated B- and T-lymphocytes. ${ }^{4-6,43}$ Although activated $T$ cells might encounter abundant Gal-1 in surrounding tissues and would become sensitive to its inhibitory effects, this protein might also be acting in an autocrine negative regulatory loop in order to shut off T-cell effector functions. Hence, we examined the regulated expression of Gal-1 during the allogenic T-cell culture (Figure 7). Expression of Gal-1 was detected at $24 \mathrm{~h}$ of cell culture, reaching its maximal levels after $48-72 \mathrm{~h}$ of allostimulation, as shown by the occurrence of both monomeric and homodimeric forms of the protein. As has been previously reported, ${ }^{2,4,7,20}$ when concentrations of Gal-1 raise signifi-

Table 1 Effect of Gal-1 on TGF- $\beta$-induced growth inhibition of Mv1Lu cells

\begin{tabular}{lcc}
\hline & $\begin{array}{c}\text { Non-acidified } \\
\text { conditions }\end{array}$ & $\begin{array}{c}\text { Acidified } \\
\text { conditions }\end{array}$ \\
Treatment & c.p.m. \pm S.E.M. $\times \mathbf{1 0}^{\mathbf{4}}$ & c.p.m. \pm S.E.M. $\times \mathbf{1 0}^{\mathbf{4}}$ \\
\hline Medium & $26.56 \pm 0.4$ & $26.35 \pm 2.9$ \\
Gal-1 $4 \mu \mathrm{g} / \mathrm{ml}$ & $24.88 \pm 0.8$ & $26.49 \pm 1.7$ \\
Gal-1 $40 \mu \mathrm{g} / \mathrm{ml}$ & $26.67 \pm 1.0$ & $23.48 \pm 7.2$ \\
\hline
\end{tabular}

Acidified or non-acidified supernatants collected after different periods of allostimulation in the absence or in the presence of Gal-1, were added at different dilutions to TGF- $\beta$-sensitive Mv1Lu cells $\left(4 \times 10^{5}\right.$ cells $\left./ \mathrm{ml}\right)$. Plates were incubated for $20 \mathrm{~h}$ and $\left[{ }^{3} \mathrm{H}\right] \mathrm{TdR}$ was added for an additional period of $4 \mathrm{~h}$. A standard growth response curve using recombinant TGF- $\beta 1$ was set up and the levels of total (acidified) or bioactive (non-acidified) TGF- $\beta$ were referred to the standard curve and expressed as c.p.m. \pm S.E.M. Data corresponding to supernatants collected 72 post-allostimulation are shown. Similar results were obtained with supernatants collected after different time periods
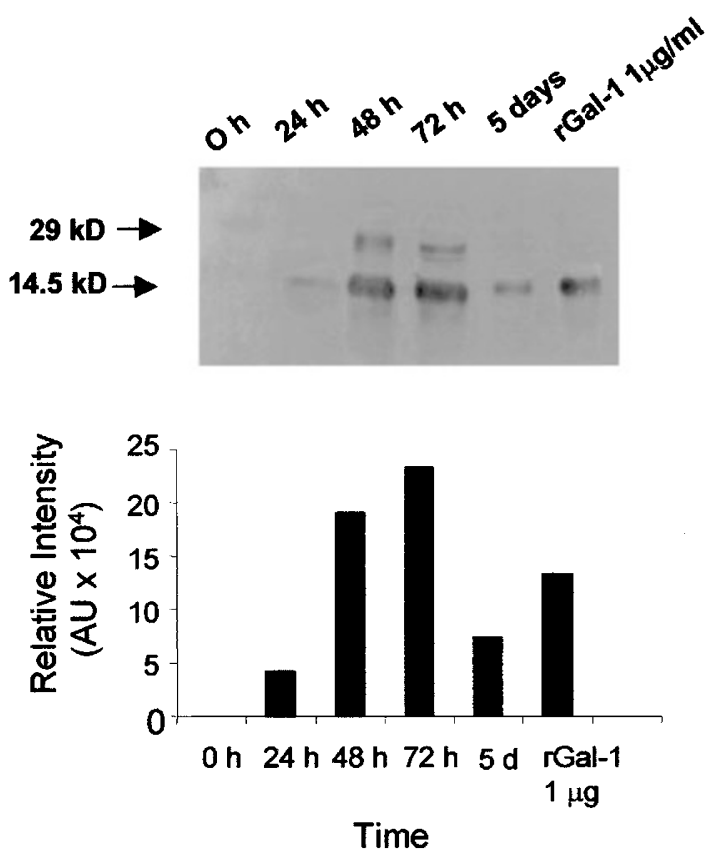

Figure 7 Endogenous Gal-1 is differentially expressed during the alloimmune response. Fully HLA-mismatched responder $\left(1 \times 10^{5}\right.$ cells $\left./ \mathrm{ml}\right)$ and mitomycin-treated stimulator PBMCs $\left(1 \times 10^{5} \mathrm{cells} / \mathrm{ml}\right)$ were co-cultured for the indicated periods. Cells were then harvested and lysed in the presence of protease inhibitors. Equal amounts of protein were subjected to SDS-PAGE on a $15 \%$ polyacrylamide slab gel and immunoblotted with an anti-Gal-1 polyclonal Ab $(1: 2000)$. Recombinant Gal-1 $(1 \mu \mathrm{g})$ was used as a control of positive reaction. Immunoreactive protein bands were semiquantified by densitometry and expressed as relative arbitrary units (AU). Results are representative out of three independent experiments using different healthy donors

cantly, the $29 \mathrm{kDa}$ dimeric band appears even under reducing conditions, since the subunits self-associate by hydrogen bonding. The absence of an immunoreactive protein band at the initiation of the cell culture $(0 \mathrm{~h})$ and its substantial increase during allostimulation, suggest that this protein might play a key role during the effector phase of the alloimmune response.

\section{Discussion}

The present study is aimed at validating the concept of an immunoregulatory role for Gal-1 in the course of the allogenic T-cell response. Induction of partial tolerance in alloreactive lymphocytes by a lectin-dependent process is clearly suggestive of a natural mechanism to extend allograft survival and achieve homeostasis in immune privilege tissues. Here we show that Gal-1 suppresses the alloimmune response in a dose- and carbohydrate-regulated manner and provide evidence of the molecular mechanisms implicated in this process.

Research over the past decade identified specific immunosuppressive properties for $\beta$-galactoside-binding proteins in experimental models of autoimmunity and chronic inflammation. ${ }^{20,21,24,44}$ However, only in the last few years Gal-1 has been demonstrated to exert its effects through apoptotic and non-apoptotic mechanisms. We have 
shown that recombinant Gal-1 or its genetic delivery ameliorated inflammation in an experimental model of rheumatoid arthritis, a T-cell mediated autoimmune disease. ${ }^{20}$ Treatment with syngeneic fibroblasts engineered to secrete Gal-1 at the day of the disease onset, resulted in increased susceptibility to activation-induced T-cell death. This biological effect was antigen-specific, required signaling via the TCR and was also accompanied by a strong shift from Th1 to Th2 cytokine production. ${ }^{20}$

Recombinant Gal-1 has been shown to induce apoptosis of activated $T$ cells through recognition of selectively glycosylated receptors. ${ }^{14-16}$ Recent studies showed that this $\beta$-galactoside-binding protein acts by antagonizing $\mathrm{T}$ cell responses requiring complete TCR signal transduction, but enhances those functions requiring only partial TCR- $\zeta$ chain phosphorylation, such as apoptosis. ${ }^{17}$ Since, alloreactive $T$ cells represent the major barrier for successful allograft acceptance, ${ }^{25,26}$ in the present study we explored the possibility that Gal-1 could be potentially used to achieve allospecific tolerance. We showed that Gal-1 induced apoptosis of a proportion of the activated T-cell population and susceptibility to cell death increased significantly in the course of the alloimmune response, as shown by the modulation of $\mathrm{Bcl}-2$ protein levels and the degree of subdiploid DNA content. However, the extent of inhibition of thymidine uptake induced by Gal-1 is sufficiently higher to predict that additional 'non-apoptotic' mechanisms might contribute to the immunosuppressive effects of this carbohydrate-binding protein. Among those 'non-apoptotic' mechanisms, inhibition of antigen receptor signaling and modulation of cytokine production should be considered.

Research over the last few years suggested that induction of leukocyte apoptosis might be crucial in the establishment of new protocols for allograft tolerance. ${ }^{27-34}$ In this sense, Bittencourt et al. ${ }^{28}$ reported that intravenous injection of apoptotic leukocytes enhances bone marrow engraftment across major histocompatibility barriers. Moreover, Li et al. ${ }^{44}$ showed that restoration of apoptotic activity within the peripheral alloreactive $\mathrm{T}$ cell population is critical for liver allograft survival and tolerance induction. While Fas-Fas ligand interactions have been shown to mediate many of those immunosuppressive effects and to play a role in the modulation of alloimmune responses, ${ }^{29-33}$ recent studies demonstrated that alloantigen-driven T-cell death mediated by Fas ligand and TNF- $\alpha$ may not be essential for the induction of allograft acceptance and suggested that alternative apoptotic pathways might participate in alloantigen-driven T-cell apoptosis. ${ }^{34}$ Interestingly, Delioukina et al. ${ }^{22}$ have recently shown that Gal-1 ameliorated the development and severity of experimental graft vs host disease (GVHD), a systemic reaction mediated by donor-derived alloreactive $\mathrm{T}$ cells.

In addition to its pro-apoptotic effects, Gal-1 has been shown to selectively modulate cytokine production. ${ }^{6,14,19,45}$ In this regard, we found a decrease of intracellular IFN- $\gamma$ following exposure of alloreactive lymphocytes to this carbohydrate-binding protein, which was not related to the pro-apoptotic effects of Gal-1. Since TGF- $\beta$ is a major immunosuppressive cytokine and has recently been proposed to play a major role in alloantigen-specific T-cell hyporesponsiveness, ${ }^{40,41}$ we explored whether the powerful immunosuppressive effects of Gal-1 were also supported by TGF- $\beta$-dependent mechanisms. Using immunochemical and sensitive functional assays, we demonstrated that Gal1 does not increase the levels of latent or bioactive TGF- $\beta$. Moreover, neutralization of endogenous TGF- $\beta$ did not prevent Gal-1-induced inhibition of the alloimmune response, suggesting that the immunosuppressive properties of this carbohydrate-binding protein, at least in the allogeneic T-cell model, do not rely on TGF- $\beta$-dependent mechanisms.

One of the main findings of our study is undoubtedly the potential of exogenous IL-2 to overcome Gal-1-induced inhibition of the alloimmune response, when added $24 \mathrm{~h}$ after the initiation of the cell culture and to prevent Gal-1induced apoptosis. In this sense, susceptibility to Gal-1induced immunosuppression and apoptosis might be carefully regulated not only by specific saccharide ligands, but also by IL-2-mediated signaling on activated $T$ cells. Accordingly, IL-2 has been shown to rescue antigenspecific $T$ cells from apoptosis induced by radiation, glucocorticoids and growth factor withdrawal by selective induction of $b c /-2$ or $b c l-x L$ anti-apoptotic gene expression. ${ }^{38,39}$

Since many apoptotic stimuli, such as Fas ligand, TNF- $\alpha$ and TRAIL deliver death signals through recruitment of a series of aspartic acid-specific proteases known as caspases, ${ }^{46}$ while other stimuli function independently of caspase activation, ${ }^{36,37}$ we took advantage of the allogenic T-cell model to investigate the involvement of caspases in Gal-1-induced apoptosis. Under our experimental conditions, treatment of alloreactive lymphocytes with a broad range caspase inhibitor (ZVAD-fmk), was able to overcome cell growth inhibition triggered by Gal-1, suggesting that this $\beta$-galactoside-binding protein transduces inhibitory/ death signals through activation of caspases.

Since Gal-1 is highly expressed in activated lymphocytes, ${ }^{5}$ we finally investigated the regulated expression of this protein in the course of a human allogeneic T-cell response. Expression of endogenous Gal-1 peaked after 2 to 3 days of allostimulation, suggesting a role for this protein during the effector phase of the alloresponse. Similarly, Blaser et al. ${ }^{5}$ reported the presence of Gal-1 mRNA in antigen-stimulated, but not in resting $\mathrm{CD}^{+} \mathrm{T}$ cells. Moreover, we have previously shown increased expression of Gal-1 in activated $B$ cells that received signals via cross-linking of the $B$-cell receptor $(B C R)$ and CD $40^{6}$ and in PMA- and FMLP-stimulated macrophages. ${ }^{3,4}$

In addition to the potential use of Gal-1 in preventing allograft rejection, this protein might also participate in the establishment of immune privilege in tissues such as testis, placenta and the eye, which have the ability to support allogenic and xenogenic tissue grafts. ${ }^{47}$ The specific ability of Gal-1 to downregulate T-cell responses and its high expression in immunologically privileged sites, in which transplanted allogenic tissues are protected from a local immune response, ${ }^{47}$ suggest that this $\beta$-galactoside-binding protein might be relevant for tolerance induction and could be potentially used to avoid chronic graft rejection. Immune 
privilege has been proposed to be an active process that employs evolutionarily conserved mechanisms to induce cell death and immune tolerance. ${ }^{47}$ Finally it has recently been postulated that bone marrow transplantation is the way to treat certain autoimmune diseases such as rheumatoid arthritis and multiple sclerosis. ${ }^{48,49}$ The hypothesis behind this proposal is that 'old memory' of autoimmune disease will be deleted by radiation therapy while newly transplanted bone marrow will be tolerized to current autoantigens driving the immune response. This resetting of the immune system may also be induced by Gal-1 treatment. Further experiments will be required to evaluate these interesting clinical applications.

Results presented herein provide the first experimental evidence implicating Gal-1 in the modulation of alloantigen specific T-cell responses. Investigation of the molecular mechanisms leading to immune tolerance, T-cell suicide and homeostasis will contribute to delineate novel therapeutic strategies to prevent graft rejection, GVHD, DTH reactions and autoimmunity, avoiding generalized immunosuppression. $^{50}$

\section{Materials and Methods}

\section{Reagents and antibodies}

RPMI-1640 medium, PHA, protease inhibitors cocktail, iodoacetamide, thiodigalactoside (TDG), HRP-conjugated goat anti-rabbit IgG, NP-40 and propidium iodide were purchased from Sigma Chemical Co. (St. Louis, MO, USA). Electrophoretic reagents were from Bio-Rad (Richmond, CA, USA). Fetal calf serum (FCS) and L-glutamine were from Life Technologies (Paisley, UK). Recombinant human placenta Gal-1 was produced as described, ${ }^{51}$ resuspended, stored in $8 \mathrm{mM}$ DTT at $-70^{\circ} \mathrm{C}$ and used in all procedures in medium or PBS containing $1.0 \mathrm{mM}$ DTT (PBS/DTT). The anti-Gal-1 polyclonal Ab was obtained in rabbits as described. ${ }^{20,51}$ The anti-Bcl-2 Ab (Bcl-2 $\left.\Delta \mathrm{C} 21\right)$ was from Santa Cruz Biotechnol. (Santa Cruz, CA, USA). The TGF- $\beta$ neutralizing $A b$ and the TGF- $\beta$ detection kit were from R\&D Systems (Palo Alto, CA, USA). Phycoeritrin (PE)-conjugated anti-IFN- $\gamma$ and PEconjugated anti-human CD45R0 mAb were from Becton Dickinson (San José, CA, USA). The caspase inhibitor ZVAD-fmk (benzyloxycarbonyl-Val-Ala-Asp-fluoromethylketone) was from Enzyme System Products (Livermore, CA, USA). All other chemical reagents were commercially available analytical grade.

\section{PBMC isolation}

Peripheral blood mononuclear cells (PBMCs) were prepared from anticoagulated venous blood taken from healthy adult volunteers by Ficoll-Paque ${ }^{(i x}$ Plus (Amersham Pharmacia Biotech, Uppsala, Sweden) gradient centrifugation. Cells were extensively washed and resuspended in RPMI-1640 supplemented with $10 \%$ heat inactivated pooled normal human $A B$ serum, sodium pyruvate, glutamine and penicillin-streptomycin.

\section{Allogeneic stimulation}

Peripheral blood mononuclear cells were resuspended in complete RPMI-1640 $\left(1 \times 10^{5}\right.$ cells/well $)$ and stimulated with mitomycin-treated allogeneic cells $\left(1 \times 10^{5}\right.$ cells/well) from fully-HLA mismatched donors (previously typed by SSOP at the Tissue Typing Section of our laboratory). Cells were cultured for 5 days in 96-well ' $U$ '-bottomed polystyrene plates (Becton Dickinson, Franklin Lakes, NJ, USA) in the absence or in the presence of Gal-1 (2, 4, 40 or $100 \mu \mathrm{g} / \mathrm{ml}$ resuspended in PBS/DTT). Cultured cells were then used for proliferation assays, flow cytometry, apoptosis assays, Western blot analysis or TGF- $\beta$ detection. To test the $\beta$-galactoside-specificity of the inhibitory effect, cells were also exposed to different concentrations of Gal-1 in the presence of 0.1 M TDG. The participation of endogenous Gal-1 in the allogeneic T-cell response, was explored by incubating cells with the specific anti-Gal-1 Ab $(1: 100)$. To investigate whether the suppressive activity of Gal-1 involved TGF- $\beta$-dependent mechanisms, a neutralizing pan-specific TGF- $\beta$ mAb (which recognizes TGF$\beta_{1}, \beta_{2}, \beta_{3}$ and $\beta_{5}$ ) (R\&D Systems, Palo Alto, CA, USA) was added at a concentration of $5 \mu \mathrm{g} / \mathrm{ml}$ to allogenic cell cultures. To test whether $\mathrm{Gal}-$ 1 triggered caspase activation, cells were also incubated with this $\beta$ galactoside-binding protein in the presence of 10 or $50 \mu \mathrm{M}$ ZVAD-fmk, a broad cystein protease inhibitor. In another set of experiments, cells were exposed to Gal-1 in the presence of $20 \mathrm{U} / \mathrm{ml}$ of recombinant IL-2 added at different times of the cell culture. Cells cultured in the presence of IL-2 alone were used to test submitogenic concentrations of this cytokine Percentages of inhibition of cell proliferation were calculated as follows: $100-100 \times$ (c.p.m. $x$-c.p.m.autologous)/ (c.p.m. allogeneic -c.p.m. autologous), where ' $x$ ' represents the different experimental conditions described above.

\section{Proliferation assays}

After the indicated periods, cells were pulsed with $1 \mu \mathrm{Ci} /$ well of methyl- ${ }^{3} \mathrm{H}$-thymidine $\left[{ }^{3} \mathrm{H}\right] \mathrm{TdR}$ (NEN, Boston, MA, USA) during the last $18 \mathrm{~h}$ of cell culture and harvested on glass fiber filters using a Packard Filtermate cell harvester (Packard Instruments, LaGrange, IL, USA). Incorporated radioactivity was measured in a liquid scintillation $\beta$ counter (Packard Instruments). All tests were conducted in triplicate. Results were expressed as mean c.p.m. of triplicate wells \pm S.E.M. and percentages of inhibition were calculated as described above.

\section{Apoptosis assays}

Following allogenic stimulation, cells were harvested after different time periods, washed with ice-cold PBS, fixed in $1 \mathrm{ml} 70 \%$ ethanol and processed for analysis of hypodiploid DNA content by propidium iodide (PI) staining as described by Nicoletti et al. ${ }^{52}$ Briefly, after extensive washing cell pellets were gently resuspended in $1 \mathrm{ml}$ hypotonic fluorochrome solution $(50 \mu \mathrm{g} / \mathrm{ml}$ PI diluted in $0.1 \%(\mathrm{w} / \mathrm{v})$ sodium citrate plus $0.1 \%(\mathrm{v} / \mathrm{v})$ Triton $\mathrm{X}-100)$ and kept at $4{ }^{\circ} \mathrm{C}$ for $3 \mathrm{~h}$ in the dark. The PI fluorescence emission of individual nuclei was filtered through 585/ $42 \mathrm{~nm}$ band pass filter. Ten thousand events were acquired in a Cytoron Absolute cytometer ${ }^{\circledR}$ (Ortho Diagnostic, Raritan, NJ, USA). Results were analyzed using the WinMDI software ${ }^{\circledR}$. The frequency of apoptotic cells was assessed by evaluating the percentage of subdiploid nuclei in the $<2 \mathrm{~N}$ DNA peak. Percentages of subdiploid DNA content were also determined after subtraction of the corresponding controls in the absence of Gal-1, as follows: [subdiploid (galectin-1)- subdiploid (control)/100-subdiploid (control)] $\times 100$ at the different time periods.

Sensitivity of $\mathrm{CD} 45 \mathrm{R}^{+}$cells to Gal-1-induced apoptosis was

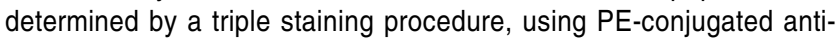
human CD45R0 mAb (Becton Dickinson, San José, CA, USA) and a FITC-conjugated annexin-V/PI kit, as per the manufacturer's recommendations (Immunotech, Marseille, France). Flow cytometry data was acquired and analyzed as above. 


\section{Intracytoplasmic IFN- $\gamma$ detection}

After allogenic stimulation, cells were analyzed for intracellular IFN- $\gamma$ production. Briefly, cells were extensively washed, adjusted to $0.1 \mathrm{M}$ TDG or lactose to dissociate Gal-1-agglutinated cell clumps and fixed with $4 \%$ paraformaldehyde. Cells were then permeabilized with $1 \%$ saponin and simultaneously incubated for $30 \mathrm{~min}$ at $4^{\circ} \mathrm{C}$ with $\mathrm{PE}-$ conjugated anti-human IFN- $\gamma$ mAb. Ten thousand events were acquired in a Cytoron Absolute cytometer ${ }^{\mathbb{R}}$ (Ortho Diagnostic System, Raritan, NJ, USA) and analyzed as above. Annexin-V positive cells were electronically gated out to avoid nonspecific uptake of Abs by dead cells and to analyze only the viable non-apoptotic cell population.

\section{Western blot assays}

To analyze modulation of $\mathrm{Bcl}-2$ expression levels, cells were cultured in the absence or in the presence of Gal-1 $(40 \mu \mathrm{g} / \mathrm{ml})$ and collected after different time periods of allostimulation. Cells cultured in medium alone were also obtained to analyze modulation of endogenous $\mathrm{Bcl}-2$ and Gal-1 expression. Western blot analysis was performed essentially as described. ${ }^{4,15}$ Medium was carefully removed and cells were extensively washed with PBS at room temperature. Then, cell pellets were mixed gently with $1 \mathrm{ml}$ ice-cold lysis buffer (PBS containing $5 \mathrm{mM}$ EDTA, 1\% NP-40, 0.5\% sodium deoxycholate, $0.1 \%$ SDS, $142.5 \mathrm{mM} \mathrm{KCl}, 5 \mathrm{mM} \mathrm{MgCl}$, $10 \mathrm{mM}$ HEPES, pH 7.2) with freshly added protease inhibitor cocktail (0.2 mM PMSF, $0.1 \%$ aprotinin, $0.7 \mu \mathrm{g} / \mathrm{ml}$ pepstatin and $1 \mu \mathrm{g} / \mathrm{ml}$ leupeptin) and incubated for $30 \mathrm{~min}$ on ice. Samples were finally centrifuged at $15000 \times g$ for $20 \mathrm{~min}$ at $4^{\circ} \mathrm{C}$ and the supernatant fluids, representing the whole cell protein lysates, were stored at $-70^{\circ} \mathrm{C}$ until use. Protein concentration was estimated by using the micro-BCA ${ }^{\circledR}$ Protein Assay reagent kit (Pierce, Rockford, IL, USA).

SDS-PAGE was performed in a Miniprotean II electrophoresis apparatus (Bio Rad, Richmond, CA, USA) as described by Laemmli. ${ }^{53}$ Equal amounts of proteins ( $30 \mu \mathrm{g}$ per each lane) were diluted in sample buffer and resolved on a $15 \%$ separating polyacrylamide slab gel. After electrophoresis, the separated proteins were transferred onto nitrocellulose membranes and probed with a 1:2000 dilution of the anti-Bcl-2 polyclonal Ab (Santa Cruz Biotechnol, CA, USA) or a $1: 2000$ dilution of the anti-Gal-1 polyclonal $A b$ as described. ${ }^{15,20}$ Blots were then incubated with a 1:3000 dilution of a HRP-conjugated anti-rabbit IgG and developed using an enhanced chemoluminescence (ECL) detection kit (Amersham, Uppsala, Sweden). Recombinant Gal-1 $(1 \mu \mathrm{g})$ was used as a positive control for Western blot detection. Control of specific immunoreaction was performed by incubation of the blots with a rabbit preimmune serum. The anti-Gal-1 $\mathrm{Ab}$ was found to be monospecific since it did not recognize other galectins, such as Gal-3. ${ }^{6}$ Equal loading and absence of protein degradation were checked by Ponceau S staining (Sigma, St. Louis, MO, USA) and using an anti- $\alpha$-tubulin (DM1A) mAb as described. ${ }^{3}$ TGF- $\beta$ expression (TGF- $\beta_{1}, \beta_{2}, \beta_{3}$ and $\beta_{5}$ ) was analyzed by Western blot at different time periods of incubation with Gal-1, using the TGF- $\beta$ detection kit, following the manufacturer's recommended protocol (Cat. number DK-20-PB; R\&D Systems, Palo Alto, CA, USA). Rainbow protein molecular weight markers were from Bio Rad (Richmond, CA, USA). The immunoreactive protein bands were analyzed with a Fotodyne Image Analyzer ${ }^{\circledR}$ (Fotodyne, Inc., Hartland, WI, USA). Results were expressed as relative densitometric values by means of the Image Quant software.

\section{TGF- $\beta$ bioassay}

Culture supernatants were assayed for TGF- $\beta$ activity by their ability to inhibit the growth of the TGF- $\beta$-sensitive mink lung epithelial cell line
(Mv1Lu), as described by Danielpour et al. ${ }^{42}$ Briefly, cell supernatants from allogenic T-cells cultured in the absence or presence of Gal-1 (4 and $40 \mu \mathrm{g} / \mathrm{ml}$ ) were collected at different time periods of allostimulation. Mv1Lu cells were seeded at $2 \times 10^{4}$ cells/50 $\mu \mathrm{l} /$ well into a 96 -well plate (Corning, NY, USA) in DMEM supplemented with $0.4 \%$ FCS. An hour later, $50 \mu \mathrm{l}$ of different dilutions of untreated supernatants were assayed to measure only bioactive TGF- $\beta$. Alternatively, supernatants were treated with $5 \mathrm{~N} \mathrm{HCl}$ followed by neutralization with $\mathrm{NaOH}$ / HEPES to measure total TGF- $\beta$ (bioactive and latent). In parallel, cells were treated with different concentrations of purified TGF- $\beta_{1}$ ranging from 0.05 to $5 \mathrm{ng} / \mathrm{ml}$ to be used as a standard curve. Plates were incubated for $20 \mathrm{~h}$. Then, cells were pulsed with $1 \mu \mathrm{Ci} /$ well $\left[{ }^{3} \mathrm{H}\right] \mathrm{TdR}$ (NEN, Boston, MA, USA) and plates were incubated for a further 4$8 \mathrm{~h}$. Cells were then lysed with $6 \mathrm{M}$ guanidinium chloride and harvested in glass hollow fibers with a multi-well cell harvester (Nunc, Roskilde, Denmark). Incorporated radioactivity was measured by a liquid scintillation $\beta$-counter. All tests were conducted in triplicate. Results were expressed as mean c.p.m. of triplicate wells \pm SEM.

\section{Statistical analysis}

The significance of the results was analyzed by Student's $t$-test performed using the GraphPad software (GraphPad, San Diego, CA, USA).

\section{Acknowledgements}

This study was supported by grants to GA Rabinovich from Fundación Sales and Fundación Roemmers, a grant to RE Ramhorst from Fundación Roemmers and a grant to $L$ Fainboim from the University of Buenos Aires (TM51). L Fainboim and EB Kier-Joffé are members of the scientific career from CONICET. We thank Drs. J Hirabayashi and $\mathrm{K}$ Kasai for kindly providing recombinant Gal-1. We also thank Mrs. F Quiroga and Mr. M Barbosa for technical assistance in FACS analysis and Drs. E Chuluyan and N Zwirner for continuous support.

\section{References}

1. Rabinovich GA (1999) Galectins: an evolutionarily conserved family of animal lectins with multifunctional properties; a trip from the gene to clinical therapy. Cell Death Differ. 6: 711-722

2. Baum LG, Pang M, Perillo NL, Wu T, Delegeane A, Uittenbogaart CH, Fukuda M and Seilhamer J (1995) Human thymic epithelial cells express and endogenous lectin, galectin-1, which binds to core 2 O-glycans on thymocytes and $\mathrm{T}$ lymphoblastoid cell lines. J. Exp. Med. 181: 877-887

3. Rabinovich GA, Castagna LF, Landa CA, Riera CM and Sotomayor CE (1996) Regulated expression of a galectin-1-like protein in activated rat macrophages. J. Leuk. Biol. 59: 363-370

4. Rabinovich GA, Iglesias MM, Modesti NM, Castagna LF, Todel CW, Riera CM and Sotomayor CE (1998) Activated rat macrophages produce a galectin-1-like protein that induces apoptosis of $\mathrm{T}$ cells: biochemical and functional characterization. J. Immunol. 160: 4831-4840

5. Blaser C, Kaufmann M, MullerC, Zimmerman C, Wells V, MallucciLand PircherH (1998) Beta-galactoside-binding protein secreted by activated T cells inhibits antigen-induced proliferation of T cells. Eur. J. Immunol. 28: 2311-2319

6. Zúñiga E, Rabinovich GA, Iglesias MM and Gruppi A (2001) Regulated expression of galectin-1 during B-cell activation and implications for T-cell apoptosis. J. Leuk. Biol. 70: 73-79

7. Cooper DNW (1997) Galectin-1: secretion and modulation of cell interactions with laminin. Trends Glycosci. Glycotechnol. 9: 57-67

8. Sotomayor CE and Rabinovich GA (2000) Galectin-1 induces central and peripheral cell death: implications in T-cell physiopathology. Dev. Immunol. 7: $117-129$ 
9. Perillo NL, Uittenbogaart C, Nguyen J and Baum LG (1997) Galectin-1, an endogenous lectin produced by thymic epithelial cells, induces apoptosis of human thymocytes. J. Exp. Med. 185: 1851-1858

10. Pace KE, Lee C, Stewart PL and Baum LG (1999) Restricted receptor segregation into membrane microdomains occurs on human $T$ cells during apoptosis induced by galectin-1. J. Immunol. 163: 3801-3811

11. Walzel H, Blach M, Hirabayashi J, Kasai KI and Brock K (2000) Involvement of CD2 and CD3 in galectin-1-induced signaling in human Jurkat T-cells. Glycobiology 10: 131-140

12. Pace KE, Hahn HP, Pang M, Nguyen JT and Baum LG (2000) CD7 delivers a proapoptotic signal during galectin-1-induced T cell death. J. Immunol. 165:2331-2334

13. Kopitz J, Von Reitzenstein C, Burchert M, Cantz M and Gabius HJ (1998) Galectin-1 is a major receptor for ganglioside GM1, a product of the growthcontrolling activity of a cell surface ganglioside sialidase, on human neuroblastoma cells in culture. J. Biol. Chem. 273: 11205-11211

14. Vespa GNR, Lewis LA, Kozak KR, Moran M, Nguyen JT, Baum LG and Miceli MC (1999) Galectin-1 specifically modulates TCR signals to enhance TCR apoptosis but inhibit IL-2 production and proliferation. J. Immunol. 162: 799-806

15. Rabinovich GA, Alonso CR, Sotomayor CE, Durand S, Bocco JL and Riera CM (2000) Molecular mechanisms implicated in galectin-1-induced apoptosis: activation of the AP-1 transcription factor and downregulation of Bcl-2. Cell Death Differ. 7: 747-753

16. Perillo NL, Pace KE, Seilhamer JJ and Baum LG (1995) Apoptosis of T cells mediated by galectin-1. Nature 378: $736-739$

17. Chung CD, Patel VP, Moran M, Lewis LA and Miceli C (2000) Galectin-1 induces partial TCR zeta-chain phosphorylation and antagonizes processive TCR signal transduction. J. Immunol. 165: 3722-3729

18. Rabinovich GA, Modesti NM, Castagna LF, Landa CA, Riera CM and Sotomayor CE (1997) Specific inhibition of lymphocyte proliferation and induction of apoptosis by CLL-I, a $\beta$-galactoside-binding lectin. J. Biochem. 122: 365-373

19. Rabinovich GA, Ariel A, HershkovizR, HirabayashiJ, KasaiKI and Lider O (1999) Specific inhibition of T-cell adhesion to extracellular matrix and proinflammatory cytokine secretion by human recombinant galectin-1. Immunology 97: 100-106

20. Rabinovich GA, Daly G, Dreja H, Tailor H, Riera CM, Hirabayashi J and Chernajovsky $Y$ (1999) Recombinant galectin-1 and its genetic delivery suppress collagen-induced arthritis via T cell apoptosis. J. Exp. Med. 190: 385-398

21. Offner $H$, Celnik E, Bringman T, Casentini-Borocz D, Nedwin GE and Vandenbark A (1990) Recombinant human $\beta$-galactoside-binding lectin suppresses clinical and histological signs of experimental autoimmune encephalomyelitis. J. Neuroimmunol. 28: 177-184

22. Delioukina ML, Blackall DP, Emmanoulides CD, Nanigian DB, Choi R, Luo J, Territo MC, Baum LG and Baldwin GC (1999) Galectin-1 ameliorates the development and severity of GVHD in a murine model. Blood 94: 392a

23. Rabinovich GA, Sotomayor CE, Riera CM, Bianco I and Correa SG (2000) Evidence of a role for galectin-1 in acute inflammation. Eur. J. Immunol. 30: 1331-1339

24. Santucci L, Fiorucci S, Cammilleri F, Servillo G, Federici B and Morelli A (2000) Galectin-1 exerts immunomodulatory and protective effects on concanavalin Ainduced hepatitis in mice. Hepatology 31: 399-406

25. Auchincloss H, Sykes M and Sacks DH (1998) Transplantation Immunology. In Fundamental Immunology, 4th Ed, Paul W, ed (Philadelphia: W.E. LippincottRaven) pp. 1175-1181

26. Sherman LA and Chattopadhyay S (1993) The molecular basis of allorecognition. Annu. Rev. Immunol. 11: 385-402

27. Zavazava $\mathrm{N}$ and Kabelitz $\mathrm{D}(2000)$ Alloreactivity and apoptosis in graft rejection and transplantation tolerance. J. Leuk. Biol. 68: 167-174

28. Bittencourt MC, Perruche S, Contassot E, Fresnay S, Baron MH, Angonin R Aubin F, Herve P, Tiberghien P and Saas P (2001) Intravenous injection of apoptotic leukocytes enhances bone marrow engraftment across major histocompatibility barriers. Blood 98: $224-230$

29. Wang XY, Sun J, Wang C, France M and Sheil AG (2001) Effect of liver transplantation on islet allografts: upregulation of Fas ligand and apoptosis of $T$ lymphocytes are associated with islet graft tolerance. Transplantation 71: 102 111

30. Li W, Lu L, Wang Z, Wang L, Fung JJ, Thomson AW and Qian S (2001) IL-12 antagonism enhances apoptotic death of $T$ cells within hepatic allografts from Flt3-ligand treated donors and promotes graft acceptance. J. Immunol. 166: $5619-5628$
31. Bellgrau D, Gold D, Selawry H, Moore J, Franzusoff A and Duke RC (1995) A role for CD95 ligand in preventing graft rejection. Nature 377: 630-632

32. O'Flaherty E, AliS, Petit SJand Kirby JA (1998) Examination of the sensitivity of T cells to Fas ligation. Transplantation 66: 1067-1073

33. Dulat HJ, von Grumbkow C, Baars W, Schroder N, Wonigeit K and Schwinzer R (2001) Down-regulation of human alloimmune responses by genetically engineered expression of CD95 ligand on stimulatory and target cells. Eur. J. Immunol. 31: 2217-2226

34. Wagener ME, Konieczny BT, Dai Z, Ring GH and Lakkis FG (2000) Alloantigendriven $T$ cell death mediated by Fas ligand and tumor necrosis factor-alpha is not essential for the induction of allograft acceptance. Transplantation 69: 24282432

35. Adams JM and Cory S (1998) The Bcl-2 protein family: arbiters of cell survival. Science 281: 1322-1325

36. Pettersen RD, Bernard G, Olafsen MK, Pourtein M and Lie SO (2001) CD99 signals caspase-independent T-cell death. J. Immunol. 166: 4931-4942

37. Belmokhtar CA, Hillion J and Segal-Bendirdjian E (2001) Staurosporine induces apoptosis through both caspase-dependent and caspase-independent mechanisms. Oncogene 20: 3354-3362

38. MorF and Cohen IR (1996) IL-2 rescues antigen-specific T cells from radiation or dexamethasone-induced apoptosis. J. Immunol. 156: 515-522

39. Akbar AN, Borthwick NJ, Wickremasinghe RG, Panayoitidis P, Pilling D, Bofill M, Krajewski S, Reed JC and Salmon M (1996) Interleukin-2 receptor common $\gamma$ chain signalling cytokine regulate activated $T$ cell apoptosis in response to growth factor withdrawal: selective induction of anti-apoptotic (bcl-2, bcl-xL), but not pro-apoptotic (bax, bcl-xs) gene expression. Eur. J. Immunol. 26: 294 - 299

40. ZellerJC, Panoskaltsis-Mortari A, Murphy WJ, Ruscetti FW, Narula S, Roncarolo $\mathrm{MG}$ and Blazar BR (1999) Induction of $\mathrm{CD}^{+} \mathrm{T}$ cell alloantigen-specific hyporesponsiveness by IL-10 and TGF- $\beta$. J. Immunol. 163: 3684-3691

41. Letterio JJ and Roberts AB (1998) Regulation of immune responses by TGF- $\beta$. Annu. Rev. Immunol. 16: 137-161

42. Danielpour D, Dart LL, Flanders KC, Roberts AB and Sporn MB (1989) Immunodetection and quantitation of the two forms of TGF- $\beta$ (TGF- $\beta 1$ and TGF$\beta 2)$ secreted by cells in culture. J. Cell. Phys. 138: 79-86

43. Baum LG, Seilhamer JJ, Pang M, Levine WB, Beynon D and Berliner JA (1995) Synthesis of an endogenous lectin, galectin-1 by human endothelial cells is upregulated by endothelial cell activation. Glycoconjugate J. 12: 63-68

44. Levy G, Tarrab-Hazdai R and Teichberg VI (1983) Prevention and therapy with electrolectin of experimental autoimmune myasthenia gravis in rabbits. Eur. J. Immunol. 13: 500-507

45. ZúñigaE, Gruppi A, HirabayashiJ, KasaiKand Rabinovich GA (2001) Regulated expression and effect of galectin-1 on Trypanosoma cruzi-infected macrophages: modulation of microbicidal activity and survival. Infect. Immun. 69: 6804-6812

46. Ashkenazi A and Dixit VM (1998) Death receptors: signaling and modulation. Science 281: 1305-1308

47. Griffith TS (1995) Fas ligand-induced apoptosis as a mechanism of immune privilege. Science 270: 1189-1192

48. Burt RK, Burns WH and Miller SD (1997) Bone marrow transplantation for multiple sclerosis: returning to Pandora's box. Immunol. Today 12: 559-561

49. Wicks I, Cooley H and Szer J (1997) Autologous hemopoietic stem cell transplantation: a posible cure for rheumatoid arthritis? Arthritis Rheum. 40: $1005-1011$

50. Braunberger E, Cohen JL, Boyer O, Pegaz-Fiornet B, Raynal-Raschilas N, Bruneval P, Thomas-Vaslin V, Bellier B, Carpentier A, Glotz D and Klatzmann D (2000) T-cell suicide gene therapy for organ transplantation: induction of long lasting tolerance to allogeneic heart without generalized immunosuppression. Mol. Ther. 2: 596-601

51. Hirabayashi J, Ayaki H, Soma G and Kasai KI (1989) Production and purification of a recombinant human $14 \mathrm{kDa} \beta$-galactoside-binding lectin. FEBS Lett. 250: $161-165$

52. Nicoletti I, Migliorati G, Pagliacci MC, Grignani F and Riccardi CA (1991) A rapid and simple method for measuring thymocyte apoptosis by propidium iodide staining and flow cytometry. J. Immunol. Methods 139: 271-279

53. Laemmli UK (1970) Cleavage of structural proteins during the assembly of the head of bacteriophage T4. Nature 227: 680-685 